\title{
Biological Markers in Alzheimer's Disease
}

Peter Bailey

\begin{abstract}
Biomarkers are required to improve our diagnostic sensitivity and specificity and to monitor the biological activity of the Alzheimer's disease (AD) in terms of the burden of neural involvement and the tempo of disease progression. Biomarkers will initially supplement our more traditional neuropsychological and imaging markers but may eventually evolve into useful surrogate endpoints in $\mathrm{AD}$ research. These markers may also provide important mechanistic clues to the pharmacological action of anti-dementia compounds. At this point, the combination of elevated cerebrospinal fluid phosphorylated TAU (CSF p-TAU) proteins and low CSF A ${ }_{1-42}$ are the only biomarkers with the sensitivity and specificity to serve as useful diagnostic biomarkers capable of distinguishing AD from other dementias in the early stages. Advances in non CSF tests is urgently required. Markers assessing the progression of disease do not necessarily require the same high disease specificity as diagnostic markers, but need to be sensitive to changes in disease state. At present, candidate markers fall under four main biological rationales: 1. Specific markers of AD neuropathology; 2. Non-specific markers of neural degeneration; 3. Markers of oxidative stress; 4. Markers of neural inflammation. It is foreseeable that a panel of such markers might prove advantageous. It will be important to develop "non-invasive " markers utilizing readily obtainable tissue samples such as serum or urine to monitor disease progression (or hopefully regression). Repeated sampling would allow for comparison with traditional neuropsychological and imaging measures. The assays themselves will need to be reproducible, reliable and relatively inexpensive. Unfortunately, these biomarkers are in the formative stages of testing and results at present are inconclusive. To facilitate biomarker development in the future it would be highly advantageous to begin to collect and store biological specimens as an adjunct
\end{abstract} to current research in AD.

RÉSUMÉ: Les marqueurs biologiques dans la maladie d'Alzheimer. Nous avons besoin de biomarqueurs pour améliorer la sensibilité et la spécificité du diagnostic et pour suivre l'activité biologique de la maladie d'Alzheimer (MA) en ce qui concerne le fardeau de l'atteinte neurologique et le rythme de progression de la maladie. Au début, les biomarqueurs serviront de supplément aux marqueurs traditionnels de neuropsychologie et d'imagerie, mais éventuellement ils pourraient devenir des critères d'évaluation de substitution dans la recherche sur la MA. Ces marqueurs pourraient également fournir des indices concernant les mécanismes d'action pharmacologique des médicaments anti-démence. Actuellement, la combinaison d'un taux élevé de protéines phosphorylées TAU dans le liquide céphalorachidien (LCR) et d'un taux bas d'Ab1-42 dans le LCR sont les seuls biomarqueurs qui ont une sensibilité et une spécificité permettant de les utiliser comme biomarqueurs diagnostiques capables de distinguer la MA des autres démences aux stades précoces. Il est urgent de développer des tests autres que les tests sur le LCR. Les marqueurs pour évaluer la progression de la maladie ne doivent pas nécessairement posséder une spécificité aussi élevée que les marqueurs diagnostiques, mais ils doivent être sensibles au changement au cours de la maladie. Actuellement, les marqueurs candidats se classent en quatre groupes principaux au point de vue biologique : 1 . Des marqueurs spécifiques de la neuropathologie de la MA;2. Des marqueurs non spécifiques de la dégénérescence neuronale; 3 . Des marqueurs du stress oxydatif; 4. Des marqueurs de l'inflammation neuronale. Il est probable qu'une batterie de ces marqueurs pourra s'avérer utile. Il sera important de développer des marqueurs non effractifs utilisant des échantillons de tissus faciles à obtenir, comme du sérum ou de l'urine, pour surveiller la progression de la maladie ou même sa régression. Un échantillonnage sérié permettrait de les comparer aux mesures traditionnelles de neuropsychologie ou d'imagerie. Les analyses devront être reproductibles, fiables et relativement peu coûteuses. Malheureusement, ces biomarqueurs sont encore en évaluation et les résultats sont non concluants. Il serait très avantageux de commencer à récolter et à conserver des spécimens biologiques dans le cadre de la recherche actuelle sur la MA pour faciliter le développement de biomarqueurs dans l'avenir.

Can. J. Neurol. Sci. 2007; 34: Suppl. 1 - S72-76

The rapid advances in Alzheimer disease (AD) biology and the forthcoming clinical trials with disease modifying therapies have heightened the urgency to develop sensitive and reliable biological markers to diagnose and monitor AD activity.

Diagnostic markers will be required to support early diagnosis and treatment of patients at risk for $\mathrm{AD}$. Of equal significance are markers with the capacity to monitor the
From the Department of Medicine, Dalhousie University, Saint John Regional Hospital, Saint John, New Brunswick, Canada.

Received October 31, 2005. AcCePted in FinAl Form November 23, 2006. Reprint requests to: Peter Bailey, Department of Medicine, Dalhousie University, Saint John Regional Hospital, Suite 5DN - 400 University Avenue, P.O. Box 2100, Saint John, New Brunswick, E2L 4L2, Canada. 
underlying biological burden of disease in terms of extent and intensity. These markers will eventually prove to be important surrogate outcome measures in clinical trials supplementing existing clinical and imaging data. Different markers will probably be required for each purpose.

\section{Diagnostic Markers}

The majority of research has been focused on developing diagnostic markers of $\mathrm{AD}$. These have centered on the core pathological biological proteiaceous products TAU and $B$ amyloid as measured in CSF.

\section{Total TAU}

TAU proteins, the constituent proteins of the intra-neuronal neurofibrillary tangle, were first reported to be elevated in CSF in 1993. ${ }^{1}$ These proteins probably are indicators of the intensity of neural degeneration. On average these proteins are 2-3 fold higher in AD CSF versus controls. Levels are increased very early in the disease process but levels do not correlate well with duration or intensity of disease. ${ }^{2}$ As a diagnostic test in 2400 AD patients vs. 1250 controls the sensitivity is $82 \%$ while specificity is $88 \% .^{3}$ Total TAU is not as accurate at distinguishing AD from Frontal Lobe Dementia (FTD) Vascular Dementia (VAD), Creutzfeld Jacob Disease or acute brain injury. ${ }^{4}$

\section{Phosphorylated TAU (P-TAU)}

In AD-TAU proteins become abnormally phosphorylated and loose their ability to facilitate the assembly of tubulin monomers into microtubules. They then aggregate in neurofibrillary tangles. ${ }^{5}$ Elisa assays for P-TAU have been developed at five phosphorylation sites. ${ }^{6}$

There is increasing evidence that CSF P-TAU discriminates adequately between $\mathrm{AD}$, normals and other neurological disorders ${ }^{7}$ notably FTD, Dementia with Lewy Bodies (DLB) and Vascular Dementia (VAD). P TAU does not rise with nonspecific brain damage unlike T-TAU. Important early evidence suggests that P-TAU can distinguish patients with Minimal Cognitive Impairment (MCI) who will progress to Alzheimer's disease from those who do not. ${ }^{8}$ P TAU elevates in CSF during the incipient stages of the disease then progressively declines as the disease progresses ${ }^{9}$ and the decline is more pronounced with advancing impairment.

At present $\mathrm{P}$ TAU at various phosphorylation sites are promising biomarkers for $\mathrm{AD}$ diagnosis. In particular, their utility in early detection and differentiation from other dementing conditions will be important. The one major practical drawback is the difficulty with CSF as a sample medium.

\section{Amyloid $\boldsymbol{B}_{1-42}$}

The major core protein deposited early in the senile plaque is $A \beta_{1-42} \quad\left(A \beta_{1-40}\right.$ being seen in blood vessels $)$. There is approximately a $50 \%$ reduction in $A \beta_{1-42}$ in $\mathrm{AD} C S F$ vs. controls. ${ }^{10}$ The reason for low levels of amyloid protein is not clear but hypothesized to be the result of sequestration of $A \beta_{1-42}$ in brain tissue. The sensitivity and specificity is in the $85-90 \%$ range when comparing $\mathrm{AD}$ patients to normal controls. It is less clear that low $A \beta_{1-42}$ distinguishes clearly between $\mathrm{AD}$ and other dementias, low levels being found in some patients with FTD, VAD and DLB. ${ }^{11}$ Amyloid $\beta_{1-42}$ in CSF may prove to be an important adjunctive marker in AD. There is poor correlation between $A \beta_{1-42}$ levels and disease duration or severity.

$A \beta_{1-42}$ can be measured in plasma although it is 100 fold lower in concentration. Levels are raised in familial and presenilin mutation patients but there is significant overlap in sporadic patients compared to controls. ${ }^{12}$ Several cross-sectional studies and two longitudinal studies investigated plasma Abeta measures in Alzheimer disease patients and controls. Most studies but one have shown that plasma $A \beta_{1-40}$ and $A \beta_{1-42}$ levels are not different in Alzheimer disease and control groups, thus minimising its diagnostic usefulness. ${ }^{13}$ There are suggestions that $A \beta_{1-42}$ is elevated in serum in some patients several years prior to symptoms. ${ }^{14}$ Subsequent studies have confirmed that there are higher levels of $A \beta_{1-42}$ in patients who subsequently demented. Over a 3 year period their levels of $A \beta_{1-42}$ subsequently declined. Serum $A \beta_{1-42}$ will not be a biomarker for disease diagnosis due to lack of sensitivity and specificity but might be useful for predicting AD risk and useful in enhancing clinical trial selection. ${ }^{15}$

\section{Combined CSF A $\beta_{1-42}$ and CSF Tau and Phospho Tau}

As one would expect studies employing the combination of low CSF $A \beta_{1-42}$ and elevated CSF TAU do provide good discriminative value for $\mathrm{AD}$ patients when compared to controls. ${ }^{16}$ When AD patients are compared to other forms of dementia such as Lewy Body,Vascular and Fronto-Temporal the sensitivity and specificity is not as clear. One recent studyhowever reported a sensitivity of $72 \%$ and specificity of 93\% when comparing AD to Fronto-Temporal dementia. ${ }^{17}$

\section{Biomarkers of Disease Intensity in Alzheimer's disease}

There have been many other attempts to develop biomarkers that monitor disease activity. ${ }^{18}$ While it would be ideal if they were disease specific there is no absolute necessity.

These markers have been developed along four basic biological rationales:

1. Alzheimer's disease specific pathologies

2. Non-specific markers of neural degeneration

3. Markers of neuroinflammation

4. Markers of excessive oxidation

\section{Markers of AD Specific Pathology}

\section{Glycosylated acetylcholinestrease (Glyc-AChE) and butyryl- cholinestrase (Glyc-BuChE)}

Acetyl- and butryryl-cholinesterase are altered in AD brain. Unusual glycolated forms of these enzymes are increased in AD brain and CSF. Transgenic mouse models disclose a similar phenomenon.

Studies suggest that CSF levels are low in early disease but rise significantly as the disease progresses. The finding is not specific to $\mathrm{AD}$ but also seen in DLB, VaD and FTD. The progressive rise with disease progression suggests a value in ongoing disease monitoring but unlikely a diagnostic role. 


\section{Non-specific Markers of Neuronal Degeneration}

Neurofilament proteins and synaptic markers represent nonspecific degenerative products of any neuropathological process. Their role would be in disease monitoring.

\section{Neurofilament Proteins}

These are structural proteins seen predominantly within large calibre axons. In any disease in which axonal destruction plays a role these molecules will be released, and $\mathrm{AD}$ is no exception..$^{20}$ Recent studies have evaluated phosphorylated forms and suggest they may be more specific for $\mathrm{AD}$ and be useful markers of disease progression.

\section{Synaptic Markers}

Synaptic loss is highly correlated to dementia severity. Utilizing isoelectrical focusing and western blot techniques synaptic constituents can be measured in concentrated CSF. Immunoreactive bands were detected against several constituent synaptic proteins; rab3a, synaptotagmin, growth associated protein (GAP-43), synaptosomal-associated protein (SNAP-25) and neurogranin. Development of assays to compare AD and control CSF is ongoing. ${ }^{21}$

\section{Markers of Neural Inflammation}

Inflammation is an important component of the pathophysiology of AD. Several inflammatory markers have been assessed as potential biomarkers of AD progression. These include: $\mathrm{C} 1 \mathrm{q}$ (the first component of compliment), the soluble interleukin-6-receptor-complex(IL-6,IL-6R,gp130), A1Antichymotrypsyn (ACT) and Melanotransferrin (p97).

\section{C1q}

$\mathrm{C} 1 \mathrm{q}$ is the first component of compliment and is very significantly increased in $\mathrm{AD}$ brain compared to controls..$^{22} \mathrm{C} 1 \mathrm{q}$ binds $\mathrm{TAU}$ and $\mathrm{AB}$ and is a potent facilitator of $\mathrm{A} \_$aggregation. ${ }^{23}$ There are significant decreases in $\mathrm{C} 1 \mathrm{q}$ in $\mathrm{AD}$ CSF compared to controls suggesting a sink phenomenon. The level of depression correlates with the degree of cognitive deficits. ${ }^{24}$

\section{Soluble interleukin-6-receptor-complex (IL-6, IL-6R, gp130)}

Interleukin-6 (IL-6) has inflammatory and potentially a neuroregulatory function in the brain and is in high concentration in $\mathrm{AD}$ brain but not in normal aging brain. It infiltrates early plaques but disappears as plaques age and may play a role in neuritic transformation. In $\mathrm{AD}$ the levels sIL-6R and sgp130, the receptors for IL6, are decreased while sIL6 remains unchanged. The work on this cytokine is still preliminary.

\section{Melanotransferrin}

Melanotransferrin (p97) is a protein with a role in iron transport in the brain. It also is found in neuroglia surrounding $\mathrm{AD}$ plaques. Levels are elevated in both $\mathrm{CSF}$ and serum in $\mathrm{AD} .{ }^{25}$ Several methodological issues have arisen with the assays which require clarification in order to assess this molecule as a potential biomarker. ${ }^{26,27}$

\section{Alpha 1 Antichymotrypsin (ACT)}

Alpha 1 Antichymotrypsin, a serine protease inhibitor, is elevated in $\mathrm{AD}$ brain and is related to the inflammatory cascade. It is present in senile plaques. There have been conflicting reports regarding the levels in serum and $\mathrm{CSF}^{28-30}$ It may increase with the severity of dementia. ${ }^{31}$

\section{MARKERS OF ExCESSIVE OXIDATION}

Oxidative stress occurs in a variety of neuro-degenerative diseases including $\mathrm{AD}^{32}$ It remains unclear whether this is a pathogenic process or a downstream effect of these diseases. Markers of Lipid and nucleic acid oxidation/peroxidation; isoprostanes, $8 \mathrm{OH} 2$ deoxyguanosine, and protein nitration, 3nitrotyrosine have been assessed.

\section{Isoprostanes}

8,12-iso-iPF 2 - $\mathrm{VI}$ is a sensitive marker for lipid peroxidation in $\mathrm{AD}$ patients. Studies have demonstrated elevated levels in urine, blood and CSF in both humans and mouse models. ${ }^{33}$ The levels correlate well with cognitive changes and this is one of the more informative new markers at present undergoing evaluation.

\section{3-Nitrotyrosine}

3-nitrotyrosine (3NT) is formed as a result of nitric oxide reacting with superoxide radicals to form a peroxynitrite. Peroxynitrite in turn reacts with tyrosine to produce 3 NT. The levels of $3 \mathrm{NT}$ are 6 -fold higher in CSF in AD vs. controls. ${ }^{34}$ Levels increase as cognitive status declines. This marker also appears promising but further longitudinal studies are required.

\section{$80 \mathrm{H} 2$ Deoxyguanosine}

$8 \mathrm{OH} 2$ deoxyguanosine (OHDG) is elevated in brain tissue and CSF in several degenerative conditions including $\mathrm{AD}$, Parkinson's and Huntington's diseases..$^{35}$ 8OHDG is thought to represent the attack of free radicals on DNA. It can also be measured in urine. The assay is complex and reliability is still being assessed and longitudinal studies will be required.

\section{Other Markers}

Several other lines of inquiry have also been suggested. Metabolites of cholesterol may be interest as there does appear to be a relationship between cholesterol metabolism and amyloid deposition. ${ }^{36}$ Recent trials have suggested that lipid lowering agents may ameliorate the course of $\mathrm{AD} .{ }^{37}$

Sulfatide, another lipid, is reported reduced in the CSF of AD and MCI patients when compared to controls. One small study demonstrated good separation between the two groups early in the disease. ${ }^{38}$ Further studies are warranted.

Several markers of astrogliosis have been assessed including glial fibrillary acidic protein (GFAP), which has proven nonspecific in $\mathrm{CSF}^{39}$ More promising are levels of glutamine synthetase, an astrocytic enzyme, involved in ammonia detoxification. There are recent encouraging results that serum levels are elevated in $\mathrm{AD} .{ }^{40}$ Clear separation from controls was found. These results require confirmation. 


\section{Conclusions}

Biomarkers are not adequately developed for general clinical practice or as clinical trial surrogate outcome markers. Further research is required. When disease-modifying treatments become available, biomarkers may prove to be the most effective means of early or predictive diagnosis in the incipient stages of disease and also a mechanism to monitor treatment effects.

This is an important phase of research in Alzheimer's disease in which large longitudinal clinical trials assessing diseasemodifying interventions are underway. The biological fluids of these cohorts of well-characterized patients will be an extraordinary resource for future biomarker research. Strategies to appropriately consent patients, collect and store samples and link the appropriate demographic and clinical profiles should be developed, a tissue bank.

\section{REFERENCES}

1. Vandermeeren M, Merken Vanmechelen J, Six A, van de Voorde J, Martin P, et al. Detection of TAU proteins in normal and Alzheimer's disease cerebrospinal fluid with a sensitive sandwich enzyme-linked immunosorbent assay. J Neurochem. 1193;61:1828-34.

2. Hansson O, Zetterberg H, Buchhave P, Londos E, Blennow K, Minhhon L. Association between CSF biomarkers and incipient Alzheimer's disease in patients with mild cognitive impairment: a follow-up study. Lancet Neurology. Vol 5 (3)228-34.

3. Andreasen N, Sjogren M, Blennow K. CSF Markers for Alzheimer's Disease: Total Tau, Phospho-tauand AB42. World J Biol Psychiatry 2003;4:147-55.

4. Blennow K, Wallin A, Agren H, Spenger C, Siegfried I, Vanmechelan. Tau protein in cerebrospinal fluid: a biochemical marker for axonal degeneration in Alzheimer's disease. Mol Chem Neuropathology. 26:231-45.

5. Iqbal K, Grundke-Iqbal I. Mechanism of Alzheimer neurofibrillary degeneration and formation of tangles. Mol Psychiatry. 1997;2: $178-80$.

6. Andreasen N, Sjogren M, Blennow K. CSF Markers for Alzheimer's Disease: Total Tau, Phospho-tau and AB42. World J Biol Psychiatry. 2003;4:147-55.

7. Kohnken R, Buerger K, Zinkowski R, Miller C, Kerkman D, DeBernardis, et al. Detection of tau phosphorylated at threonine 231 in cerebrospinal fluid of Alzheimer's disease patients. Neurosci Lett. 2000;287:187-90.

8. Burger K, Teipel S, Zinkowski R. CSF tau proteins phosphorylated at threonine 231 correlate with cognitive decline in MCI subjects. Neurology. 2002;59(4) 627.

9. Hampel H, Burger K, Kohnken R, Teipel SJ, Zinkowski R, Moeller $\mathrm{H}$, et al. Tracking Alzheimer's disease progression with cerebrospinal fluid tau protein phosphorylated at Threonine 231. Ann Neurol. 2001;49(4):545-6.

10. Andreasen N, Minthon L, Clarberg A, Daviidson P, Vanmechelen E, Vanderstichele H, Winblad B, et al. Sensitivity, specificity and stability of CSF tau in AD in a community -based sample. Neurology. 1999;53:1488-94

11. Sjogren M, Minthon L, Davidsson P, Graanerus A, Clarberg A, Vanderstichele $\mathrm{H}$, et al. CSF Levels of tau,b-amyloid-42 and GAP-43 in Frontotemporal dementia, other types of dementia and normal aging. J Neural Transm. 2000;107:563-76.

12. Tamaoka A, Sawamura N, Fukushima T, et al. Amyloid beta protein in cerebrospinal fluid of patients with Alzheimer's disease. J Neurol Sci. 1997;141:65-8.

13. Borron B, DiLuca M, Padovani A. Predicting Alzheimer dementia in mild cognitive impairment patients. Are biomarkers useful? Eur J Pharmacol. Vol 545 (1): 73-80.

14. Mayeux R, Tang MX, Jacobs DM, et al. Plasma amyloid betapeptide 1-42 and incipient Alzheimer's disease. Ann Neuro. 1999;46:412-16.
15. Mayeux R, Honig LS, Tang MX, Manly J, Stern Y, Schupf N, et al. Plasma $\mathrm{A}[$ beta]40 and $\mathrm{A}[$ beta]42 and Alzheimer's disease: relation to age, mortality, and risk. Neurology. 2003;61: 1185-90.

16. Schoonenboom NS, Pijnenburg YA, Mulder C, Rosso SM, Van Elk EJ, VanKanp GJ, et al. Amyloid beta(1-42) and phosphorylated tau in CSF as markers for early-onset Alzheimer disease. Neurology. 2004;62:1580-4.

17. Maddalena A, Papassotiropoulos A, Muller-Tillmanns B, Jung HH, Hegi T, Nitsch RM, et al. Biochemical diagnosis of Alzheimer disease by measuring the cerebrospinal fluid ratio of phosphorylated tau protein to beta-amyloid peptide42. Arch Neurol. 2003;60:1202-6.

18. Frank RA, Galasko D, Hampel H, Hardy J, Deleon M, Mehta P, et al. Biological markers for therapeutic trials in Alzheimer's disease proceedings of the biological markers working group; NIA initiative on neuroimaging in Alzheimer's disease Neurobiol Aging. 2004;24:521-36.

19. Saez-Vaero J, Fodero LR, Sjogren M, Andreasen N, Amici S, Gallai V, et al. Glycosylation of acetylcholinesterase and butyrylcholinesterase changes as a function of the duration of Alzheimer's disease. J Neurosci Res. 2003;72:520-6.

20. Rosengren L, Karlsson J, Karlsson J, Persson L, Wikkelso C, Sjogren M, et al. Neurofilament protein levels in CSF are increased in dementia. Neurology. 1999;52:1090-3.

21. Davidsson P, Puchades M, Blennow K. Identification of synaptic vesicle, pre-and postsynaptic proteins in human cerebrospinal fluid using liquid using liquid-phase isoelectric focusing. Electrophoresis.1999;20:431-7.

22. Brachova L, Lue lf, Schultz J, Rashidy T, Rogers J. Association Cortex,cerebellum, and serum concentrations of $\mathrm{C} 1 \mathrm{q}$ and factor B in Alzheimer's Disease. Mol Brain Res. 1993;18:329-34.

23. Webster S, Rogers J. Relative efficacies of amyloid beta peptide (AB) binding proteins in A beta aggregation. J Neurosci Res. 1996;46:58-66.

24. Smyth MD, Cribbs D, Tenner A, Shankle W, Dick M, Kesslak J, et al. Decreased levels of $\mathrm{C} 1 \mathrm{q}$ in cerebrospinal fluid of living Alzheimer's patients correlate with disease state. Neurobiol Aging. 1994;15:609-14.

25. Kennard ML, Feldman H, Yamada T, Jefferies WA. Serum levels of iron binding protein $\mathrm{p} 97$ are elevated in Alzheimer's disease. Nat Med. 1996;2:1230-5.

26. Feldman H, Gabathuler R, Kennard M, Nurinen J, Levy D, Foti S, et al. Serum p97 levels as an aid to identifying Alzheimer's disease. J Alzheimers Dis. 2001;3:507-16.

27. Kim DK, Seo M, Lim S, Kim J, Kim J, Carroll, et al. Serum melanotransferase, p97 as a biochemical marker of Alzheimer's disease. Neuropsychopharmacology. 2001;25:84-90.

28. Lanzrein A, Johnston C, Perry V, Jobst K, King E, Smith A, et al. Longitudinal study of inflammatory factors in serum, cerebrospinal fluid, and brain tissue in Alzheimer's disease: IL1beta, IL-6, Il-1 receptor antagonist, TNF-alpha, the soluble TNF receptors 1 and 11 and alpha-1-antichymotrypsin. Alzheimer Dis Assoc Disord. 1998;12:215-17.

29. Matsubara E, Hirai S, Amari M, Shoji M, Yamaguchi H, Okamoto K, et al. Alpha 1-antichymotrypsin as a possible biochemical marker for Alzheimer-type dementia. Ann Neuro. 1990;28:561-7.

30. Pirttila T, Mehta P, Frey H, Wisneiwski HM. Alpha 1antichymotrypsinand IL-1 beta are not increased in CSF or serum in Alzheimer's disease. Neurobiol Aging. 1994;15:313-7.

31. Licastro F, Pedrini S, Caputo L, Annoni G, Davis I, Ferri C, et al. Increased serum IL-1, IL-6 and alpha 1-antichymotrypsin in patients with Alzheimer's disease: peripheral inflammation or markers from the brain? J Neuroimmunol. 2000;103:97-102.

32. Giasson B, Lee VM, Ichiropoulos H, Trojanowski J. The relationship between oxidative stress and the pathological inclusions in Alzheimer's disease and Parkinson's disease. Free Rad Biol Med. 2002.

33. Practico D, Clark CM, Lee V, Trojanowski JQ. Increased 8, 12-isoiPF2--VI in Alzheimer's disease: correlation of a non-invasive index of lipid peroxidation with disease severity. Ann Neurol 2000;48:809-12. 
34. Tohgi $\mathrm{H}$, Abe $\mathrm{T}$, Yamazaki $\mathrm{K}$, Murata $\mathrm{T}$, Ishizaki $\mathrm{E}$, Isobe $\mathrm{C}$. Alterations of 3-nitrotyrosine concentration in the cerebrospinal fluid during aging and in patients with Alzheimer's disease. Neurosci Lett. 1999;269:53-4.

35. Lovell MA, Gabbita SP, Markesbery WR. Increased DNA oxidation and decreased levels of repair products in Alzheimer's disease ventricular CSF. J Neurochem. 1999;72:771-6.

36. Fassbender K, Simons M , Bergman C, Stoick M, Lutjohann D, Kellar P, et al. Simvinstatin strongly reduces levels of Alzheimer's disease beta-amyloid peptides Abeta 42 and Abeta 40 in vitro and in vivo. Proc Natl Acad Sci USA. 2001;98: 5856-61.

37. Simons M, Schwarzler F, Lutjoohann D, von Bergmann K, Beyreuther K, Dichgans J, et al. Treatment with simvinstatin in normocholestestrolemic patients with Alzheimer's disease: a 26 week randomized placebo-controlled double-blind trial. Ann Neurol. 2002;52:346-50.
38. Han X, Holtzman D, McKeel DW, et al. Substantial sulfatide deficiency and ceramide elevation in very early Alzheimer's disease: potential role in disease pathogenesis. J Neurochem. 2002;82:809-18.

39. Wallin A, Blennow K, Rosengren LE. Glial fibrillary acidic protein in the cerebrospinal fluid of patients with dementia. Dementia. 1996;7:267-72.

40. Takahashi M, Stanton E, Moreno JI, Jackowski G. Immunoassay for serum glutamine synthetase in serum: development, reference values and preliminary study in dementias. Clin Chem. $2002 ; 48: 375-8$ 